\title{
Partial Resistance Against Erysiphe pisi and E. trifolii Under Different Genetic Control in Lathyrus cicera: Outcomes from a Linkage Mapping Approach
}

\author{
Carmen Santos, ${ }^{1, \dagger}$ Davide Martins, ${ }^{1}$ Diego Rubiales, ${ }^{2}$ and Maria Carlota Vaz Patto ${ }^{1}$ \\ ${ }^{1}$ Instituto de Tecnologia Química e Biológica António Xavier, Universidade Nova de Lisboa, 2780-157 Oeiras, Portugal \\ ${ }^{2}$ Institute for Sustainable Agriculture, CSIC, Córdoba, E-14004, Spain
}

\begin{abstract}
Powdery mildew infections are among the most severe foliar biotrophic fungal diseases in grain legumes. Several accessions of Lathyrus cicera (chickling pea) show levels of partial resistance to Erysiphe pisi, the causal agent of pea powdery mildew, and to E. trifolii, a powdery mildew pathogen recently confirmed to infect pea and Lathyrus spp. Nevertheless, the underlying $L$. cicera resistance mechanisms against powdery mildews are poorly understood. To unveil the genetic control of resistance against powdery mildews in L. cicera, a recombinant inbred line population segregating for response to both species was used in resistance linkage analysis. An improved L. cicera genetic linkage map was used in this analysis. The new higher-density linkage map contains

screenings of the recombinant inbred line population, identifying a continuous range of resistance-susceptibility responses. Distinct quantitative trait loci (QTLs) for partial resistance against each pathogen were identified, suggesting different genetic bases are involved in the response to E. pisi and E. trifolii in L. cicera. Moreover, through comparative mapping of $L$. cicera QTL regions with the pea reference genome, candidate genes and pathways involved in resistance against powdery mildews were identified. This study extended the previously available genetic and genomic tools in Lathyrus species, providing clues about diverse powdery mildew resistance mechanisms useful for future resistance breeding of L. cicera and related species.
\end{abstract} 1,468 polymorphic loci mapped on seven major and two minor linkage groups, covering a total of $712.4 \mathrm{cM}$. The percentage of the leaf area affected by either E. pisi or E. trifolii was recorded in independent
Keywords: quantitative trait loci, genetic linkage map, powdery mildew disease, chickling pea, partial disease resistance, syntenic studies
Lathyrus cicera L. (chickling pea) is an annual cool-season grain legume belonging to the Fabeae tribe and an excellent source of protein for animal and human nutrition (Hanbury et al. 2000; Kenicer et al. 2005; Peña-Chocarro and Peña 1999). L. cicera also has an enhanced resistance to abiotic and biotic stresses, such as powdery mildew disease (Hammer et al. 2019; Vaz Patto et al. 2006a, 2007). Therefore, L. cicera is an attractive choice for environmentally sustainable feed and food production, especially in more marginal environments. It can function as a source of resistance genes to related species, such as pea (Hammer et al. 2019; Vaz Patto and Rubiales 2014; Vaz Patto et al. 2006b).

Powdery mildew is one of the most widespread and damaging airborne legume diseases (Rubiales et al. 2015). Some Lathyrus species are infected by Erysiphe pisi (Braun 1987; Vaz Patto et al. 2006a), the causal agent of powdery mildew disease in pea (Pisum sativum). Breeding for genetic resistance can reduce the number of fungicide applications for powdery mildew control (Nelson et al. 2017;

${ }^{\dagger}$ Corresponding author: C. Santos; css@itqb.unl.pt

Funding: This work was supported by the EU project LEGATO (FP7 grant agreement no. 613551), the Spanish Ministerio de Ciencia, Innovación y Universidades project AGL2017-82907-R, and the Portuguese Fundação para a Ciência e Tecnologia project PTDC/AGR-TEC/0992/2014 and Research Unit UIDB/04551/2020 (GREEN-IT - Bioresources for Sustainability). C. Santos, D. Martins, and M. C. Vaz Patto were also supported by Fundação para a Ciência e Tecnologia: CEECIND/00198/2017, Research Contract by Stimulus of Scientific Employment, Individual Support 2017 program; PD/BD/ 128498/2017, Ph.D. grant; and IF/01337/2014, Research Contract by IF 2014 program, respectively.

*The $\boldsymbol{e}$-Xtra logo stands for "electronic extra" and indicates there are six supplementary files published online.

The author(s) declare no conflict of interest.

Accepted for publication 8 May 2020.

(C) 2020 The American Phytopathological Society
Rubiales et al. 2011). Accordingly, in Pisum germplasm, three resistance genes against powdery mildew (E. pisi) have been reported: $\mathrm{er} I$ (PsMLO1), er2, and Er3 (Fondevilla and Rubiales 2012; Fondevilla et al. 2006, 2011; Harland 1948; Heringa et al. 1969; Humphry et al. 2011)

The $e r l$ gene has been used extensively in pea breeding programs because it confers a long-lasting resistance that appears to be durable. Histological studies showed that $\mathrm{erl}$ expression blocks fungus haustoria formation but is not associated with hypersensitive response (HR) (Fondevilla et al. 2006), resembling mlol gene resistance, which was later confirmed by molecular studies (Humphry et al. 2011). The observed mechanism of resistance is based on protein cross linking, hampering haustorium formation (Iglesias-García et al. 2015). In contrast, HR plays a major role in resistance against E. pisi governed by er2 and Er3 genes (Fondevilla and Rubiales 2012).

More recently, Erysiphe trifolii, the causal agent of clover powdery mildew, was also found to infect pea (Attanayake et al. 2010a), with Lathyrus spp. being potential alternative hosts (Attanayake et al. 2010b).

Knowing that $E$. trifolii is able to overcome the extensively used erl resistance in pea (Fondevilla et al. 2013), a similar scenario could be anticipated in Lathyrus spp. However, given the close phylogenetic proximity between Pisum and Lathyrus genus, Lathyrus spp. could also be a source of resistance against $E$. trifolii.

Although resistance to powdery mildew in pea has been extensively studied, little is known about the genetic basis and mechanisms of resistance against powdery mildew in Lathyrus genus. So far, very few studies have reported the occurrence of E. trifolii in Lathyrus spp., which are limited to L. pratensis and L. latifolius (Attanayake et al. 2010a; Kobes et al. 2011). In L. cicera, an Iberian collection of accessions was screened for resistance against $E$. pisi, and among the wide range of responses observed, accessions showing partial resistance were identified (Vaz Patto et al. 2007). L. cicera accessions with contrasting responses to E. pisi (partial resistance versus susceptibility) were selected and crossed to generate segregating populations (recombinant inbred lines, RILs). These accessions also showed contrasting responses to $E$. trifolii. The first $L$. cicera 
genetic linkage map published was constructed using one of these RIL populations (Santos et al. 2018). Nevertheless, a high-density map would allow higher resolution in resistance quantitative trait locus (QTL) mapping studies, desirable for the development of more efficient molecular selection tools. Diversity arrays technology (DArT) combined with next-generation sequencing platforms, known as DArTseq, has been successful as a high-throughput marker genotyping platform for several legume species linkage map development and QTL mapping studies, such as Cajanus cajan L. (Yang et al. 2011), Phaseolus vulgaris L. (Briñez et al. 2012; Oblessuc et al. 2013; Valdisser et al. 2017), Arachis hypogaea (Vishwakarma et al. 2016), Cicer arietinum L. (Thudi et al. 2011), Lupinus albus L. (Vipin et al. 2013), Glycine max L. (Vu et al. 2015), Vigna subterranea (Ahmad et al. 2016), Lens culinaris (Ates et al. 2018), Pisum fulvum (wild pea) (Barilli et al. 2018), and Pisum sativum (AznarFernández et al. 2020).

In the present study, a L. cicera RIL population was used for QTL mapping of partial resistance against both E. pisi and E. trifolii to understand the genetic basis of chickling pea resistance against powdery mildew fungi. In addition, the candidate resistance genes underlying the detected QTLs were investigated to understand $\mathrm{L}$. cicera molecular strategies against both pathogens. Finally, the available L. cicera genetic linkage map (Santos et al. 2018) was first improved by the incorporation of DArTseq markers aiming to increase the mapping resolution and was subsequently used for the QTL analysis.

\section{Materials and Methods}

Plant material. A segregating population of 103 RILs, derived from a cross between L. cicera genotypes BGE023542 and BGE008277 using the single-seed descent method, was genotyped and phenotyped in the $F_{5}$ and $F_{6}$ generations, respectively. The two parental genotypes were known to have contrasting responses to powdery mildew infection by $E$. pisi, with BGE023542 being partially resistant (disease severity $[\mathrm{DS}]=9 \%$, scored as the percentage of leaflet area coverage by mycelia) and BGE008277 being susceptible (DS $=48 \%$ ) (Vaz Patto et al. 2007). Unpublished preliminary data indicated that BGE023542 and BGE008277 also showed a contrasting response against $E$. trifolii. Therefore, the $L$. cicera BGE023542 $\times$ BGE008277 RIL population previously used for the development of the first $L$. cicera linkage map (Santos et al. 2018) was used in the present research to study the resistance against both powdery mildew species.

Phenotypic evaluation of resistance against $E$. pisi and E. trifolii. Through independent experiments, the responses of L. cicera individual RILs and parental genotypes to each powdery mildew species were studied. In each repeated experiment, five seedlings per RIL were grown in pots (one plant per pot) containing $250 \mathrm{~cm}^{3}$ of $1: 1$ sand-peat mixture in a growth chamber at $20^{\circ} \mathrm{C}$ with a 12-h light/12-h dark photoperiod. One leaflet of each seedling was detached from the uppermost fully expanded leaf from 12-day-old (for E. pisi inoculation) or 18-day-old (for E. trifolii inoculation) plants. Fifteen detached leaflets (five leaflets per genotype), with the adaxial side up, were placed on Petri dishes containing a solid medium of water-agar (4 g/liter) supplemented with filtered benzimidazole $(62.5 \mathrm{mg} / \mathrm{liter})$. Additionally, in each inoculation repetition, leaflets of the susceptible $P$. sativum cultivar Messire were added to Petri dishes to be used as an inoculation control. E. pisi isolate EpCO-01 and E. trifolii isolate CO-11B were permanently maintained on seedlings of $P$. sativum cultivar Messire in isolated air-filtered growth chambers at the Institute for Sustainable Agriculture - Consejo Superior de Investigaciones Científicas (Córdoba, Spain). Before use, the inocula were multiplied on pea seedlings to ensure a sufficient availability of spores. Three independent inoculation repetitions with $E$. pisi and two independent inoculation repetitions with $E$. trifolii were performed using a settling tower for a uniform conidial deposition to each Petri dish. For each RIL and parental genotypes, different leaflets were inoculated with $E$. pisi and with E. trifolii. Moreover, inoculations with E. pisi and E. trifolii were performed in different days to avoid spore contamination. An inoculum density of about 20 conidia/ $/ \mathrm{mm}^{2}$ for E. pisi and 10 con$\mathrm{idia} / \mathrm{mm}^{2}$ for $E$. trifolii was applied. After inoculation, Petri dishes were covered and placed in a growth chamber at $20^{\circ} \mathrm{C}$ under a photoperiod of 12-h light and 12-h dark. Seven or 8 days after inoculation for E. pisi or E. trifolii, respectively, both DS and infection type (IT) were visually estimated in the leaflets inoculated by either E. pisi or E. trifolii. DS was scored as the percentage of leaflet area covered by mycelia. IT was recorded according to a 0 to 4 scale, where 0 corresponds to no visible symptoms of disease and 4 corresponds to well-developed, freely sporulating colonies (Trabanco et al. 2012).

Genotyping-by-sequencing and data analysis. Total genomic DNA was extracted and purified from approximately $100 \mathrm{mg}$ of young fresh leaves from each RIL individual and respective parental genotypes using the DNeasy Plant Mini Kit (Qiagen, Germany) according to the manufacturer's instructions. DNA concentrations were measured in a Qubit 2.0 Fluorometer (Invitrogen, Life Technologies, Carlsbad, CA) using Qubit dsDNA BR Assay kit. DNA purity was checked by measuring the ratios of absorbance at 260/280 and 230/280 using a NanoDrop device (Thermo Scientific, Passau, Germany).

DNA for the L. cicera RIL population and the respective parental genotypes was sent to a provider (Diversity Arrays Technology Pty. Ltd., Yarralumla, ACT, Australia) for high-throughput DArTseq genotyping (Jaccoud et al. 2001). DArTseq genotyping generates two types of markers: silicoDArT and single nucleotide polymorphism (SNP) markers. SilicoDArT markers are microarray markers that are dominant and scored for the presence or absence of a single allele, whereas DArTseq-based SNPs are codominant markers (Alam et al. 2018). For each marker, parental BGE023542 allele was scored as "a" and parental BGE008277 allele was scored as "b." Each marker score for each RIL individual was then converted into "a" or "b," according to the parent accessions' scores, and "-" was used for missing values. Marker scores that showed a heterozygous pattern were also considered as "missing values." Raw data quality control was performed by removing (i) markers scored as heterozygous for parental genotypes, (ii) markers that were monomorphic or showed a minor allele frequency inferior to $5 \%$ in the RIL population, and (iii) markers containing more than $20 \%$ missing values. After marker filtering, the quality of the remaining markers was checked by inspecting some quality control parameters for DArT markers (Kilian et al. 2012) determined by the provider: the percentage of reproducibility, the overall call rate (percentage of samples for which the genotype call is either " 1 " or " 0 ," rather than missing value), and the polymorphism information content. Details and raw sequence data of each marker are given in Supplementary File S1.

Linkage map construction and comparative mapping with $\boldsymbol{P}$. sativum. The improvement of the first $L$. cicera genetic linkage map was achieved by combining the presently obtained DArTseq marker genotyping with the previously available genotypic dataset in the same RIL individuals: 163 expressed sequence tag-derived simple sequence repeat (E-SSR), 333 SNP, and five intron targeted amplified polymorphism (ITAP) markers (Santos et al. 2018). Linkage analysis and segregation distortion were analyzed using JoinMap 4.0 software (van Ooijen 2006). Markers with a severe segregation distortion $(P<0.05)$ were removed from the genotypic dataset. Groups of linked markers (linkage groups, LGs) were established using a threshold of logarithm of the odds (LOD) score $\geq 4$. Linkage map calculations were performed using all pairwise recombination estimates lower than 0.40 and a LOD score higher than 1.00, applying the Kosambi mapping function (Kosambi 1943). The reliability of the obtained map was checked by inspecting the individual LG $\chi^{2}$ mean values. Similar to the first $L$. cicera genetic linkage map (Santos et al. 2018), the present improved map orientation and the LG assignment to a chromosome were determined by a comparison with Medicago truncatula physical positions (Mt 4.0 version 1). LGs were drawn using MapChart 2.3 software (Voorrips 2002). In addition, a comparative mapping between $L$. cicera LGs and the recently released $P$. sativum reference genome (Kreplak et al. 2019) was performed. The genomic sequences of the mapped markers 
on the improved L. cicera linkage map were aligned against $P$. sativum genome assembly version $1 \mathrm{a}$, using the BLAST tool (https://urgi.versailles.inra.fr/blast/, BLASTn; e value $<1 \mathrm{e}^{-5}$, word size $=11$ ). The synteny between the genetic order of markers in LGs and the corresponding information of the physical position on the $P$. sativum genome was examined using Strudel visualization software (Bayer et al. 2011).

QTL mapping for powdery mildew resistance. Phenotypic data descriptive statistics were calculated using Genstat software (Genstat for Windows 19th edition). Graphical inspection of residuals was used to assess normality (Q-Q plot) and homogeneity of variance (residuals versus fitted values). Potential influential observations exceeding 1.5 times the interquartile range (outliers) were removed from the analysis. Analysis of variance was conducted for E. pisi and E. trifolii DS independently, using the Genstat procedure. Broad-sense heritability, representing the percentage of the genetic variance in the total phenotypic variance, was calculated using the VHERITABILITY Genstat procedure. Pearson's correlation between E. pisi and E. trifolii DS was calculated using the FCORRELATION Genstat procedure.

QTL analysis for resistance against both powdery mildew pathogens was performed using MapQTL software version 6.0 (van Ooijen 2009). The DS averages obtained across repetitions for each RIL individual against each pathogen were used for QTL analysis. Interval mapping (Lander and Botstein 1989) and multiple QTL mapping (MQM) (Jansen and Stam 1994) were applied. The significant LOD threshold corresponding to a genome-wide confidence level of $P<$ 0.05 was estimated for each trait using the permutation test with 1,000 permutations, available in MapQTL 6.0. QTLs were declared significant when LOD scores (MQM) exceeded the minimum significance genome-wide LOD threshold. The coefficient of determination $\left(R^{2}\right)$ for the marker located at the QTL peak was used to estimate the percentage of the phenotypic variance explained by the QTL. The 1-LOD support interval was also determined for each QTL LOD peak.

The additive effect for each detected QTL was estimated using the MQM procedure. For DS, negative values indicate increased resistance against powdery mildew infection, because the phenotypic data measured susceptibility.
Each significant QTL was characterized by the peak marker, the coefficient of determination $\left(R^{2}\right)$, the LOD score, the QTL interval (including 1-LOD confidence support), and the effects of the parental alleles. QTL representations were drawn using MapChart 2.3 software (Voorrips 2002). QTL nomenclature was set as follows: EpDSLG and EtDSLG, where "LG" was replaced by the number of LGs in which the QTLs were detected for E. pisi and E. trifolii DS, respectively.

Identification of candidate resistance genes underlying QTLs. Two approaches were used for identification of candidate resistance genes underlying QTLs: (i) candidate genes associated to the markers located in QTL regions (in this case the flanking markers) were predicted by the markers' sequence alignment to the legume sequence NCBI database, using the BLASTn tool; and (ii) additional candidate resistance genes located within QTL regions were identified by comparative mapping of those QTL intervals in the pea genome, using the $P$. sativum Jbrowse platform (https://www.pulsedb.org/jbrowse/). The inferred position of the QTL intervals flanking markers in the pea genome was used to delimit the pea genome regions with potential candidate resistance genes.

\section{Results}

Phenotypic data variation. All L. cicera RIL individuals showed a compatible interaction (IT $=4$ ) with both $E$. pisi and E. trifolii. This means that well-developed, freely sporulating colonies were present on each leaf surface inoculated, not causing macroscopically visible host cell necrosis (Supplementary File S2). However, for both pathogens, the DS population frequency showed a continuous distribution, ranging from 8.1 to $42.4 \%$ and from 2 to $23.8 \%$ for $E$. pisi and E. trifolii, respectively (Fig. 1). The parental genotypes showed contrasting E. pisi DS responses, with BGE023542 depicting a partial resistant phenotype $(\mathrm{DS}=18.5 \%, \mathrm{IT}=4)$, whereas BGE008277 was shown to be susceptible ( $\mathrm{DS}=38.8 \%$, IT $=4$ ). Regarding the parental genotypes' response to E. trifolii inoculation, BGE023542 presented $6.2 \%$ DS and BGE008277 presented $23.3 \%$ DS, on average. An almost absent transgressive segregation was detected for DS against both pathogens, with a fraction of the individual RILs showing a higher resistance or susceptibility than the parental genotypes (Fig. 1).
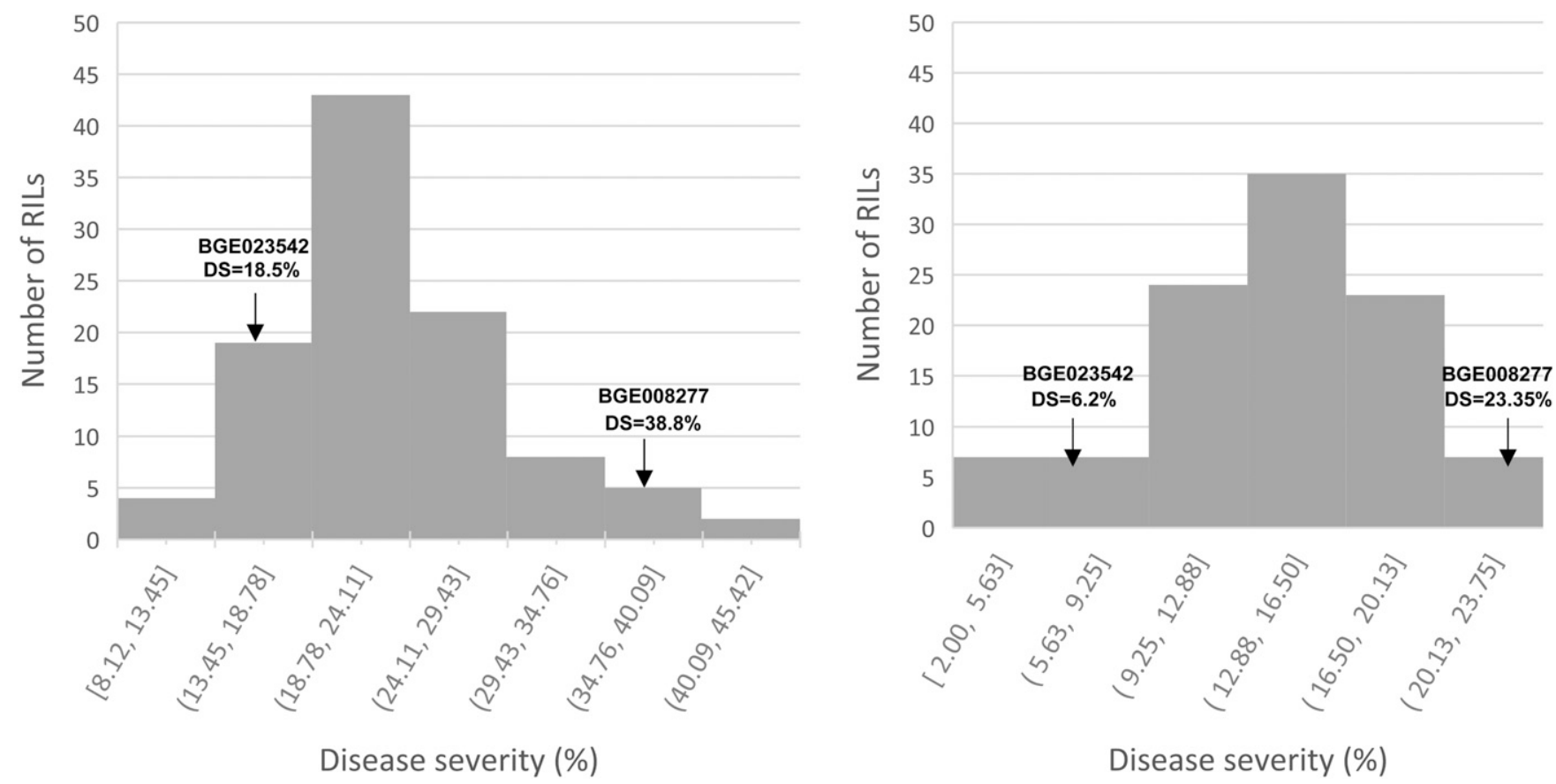

Fig. 1. Frequency distributions of disease severity (DS) 7 and 8 days after inoculation with Erysiphe pisi (left) and $E$. trifolii (right), respectively, in the Lathyrus cicera recombinant inbred lines (RILs) population under controlled conditions. The average DS values of $E$. pisi and $E$. trifolii powdery mildews of the two parental lines are indicated by the arrows. 
Because the residual's variance followed a normal distribution for both $E$. pisi and E. trifolii DS, no data transformation was applied. $E$. pisi and E. trifolii DS analysis of variance revealed the existence of a genotypic significant variation among the RIL individuals $(P<0.001)$. The calculated broad-sense heritability for $E$. pisi and $E$. trifolii DS across repetitions was 81.4 and $76.4 \%$, respectively. The $L$. cicera RILs DS responses against $E$. pisi and $E$. trifolii were weakly correlated $(0.31, P=0.0015)$.

L. cicera new high-density linkage map. Using DArTSeq technology, a total of 4,879 silicoDArT and SNP markers were scored in the RIL population (Supplementary File S1). Of these, a set of 1,045 silicoDArT markers ( $88.3 \%$ of total silicoDArT markers) and 1,283 SNPs markers (34.7\% of total SNP markers) were selected for further analysis after quality control. These selected markers presented an average polymorphism information content value of 0.45 , $99 \%$ of reproducibility, and an overall call rate of $89 \%$ (see Materials and Methods, "Genotyping-by-sequencing and data analysis"). To give further detail, 2,551 markers were removed from further analysis due to different causes: (i) $54.4 \%$ were monomorphic or presented a minor allele frequency inferior to $5 \%$; (ii) $45.3 \%$ were heterozygous in one or both parental genotypes (preventing inferring the correct segregation pattern); and (iii) $0.3 \%$ had more than $20 \%$ missing values. As a result, the construction of the high-density L. cicera linkage map was based on 2,328 DArT-based markers scored in the present study, combined with 501 markers (333 SNP, 163 E-SSR, and five ITAP) previously reported by Santos et al. (2018). From the total of 2,829 markers screened in the RILs, 1,284 markers were excluded from further analysis due to a high segregation distortion ( $\chi^{2}$ test, $P<0.05$ ) or for having identical segregation to other markers, thus making them redundant for the map construction. Additionally, one RIL individual was removed because it showed more than $25 \%$ missing data. So, in total, the linkage map was developed using data from 102 RILs screened with 1,544 polymorphic loci. From these, 1,468 markers (730 silicoDArT markers, 623 SNPs, 110 ESSRs, and five ITAPs) were successfully assigned to the LGs. The new linkage map covered a total length of $712.35 \mathrm{cM}$, with an average of $0.65 \mathrm{cM} /$ marker (Table 1). Markers were assigned to seven major LGs and two minor LGs (LG VIII and LG IX, containing 17 and 19 mapped markers, respectively) (Fig. 2, Supplementary File S3), using a LOD threshold above 4.

The total number of mapped loci per major LG ranged from 82 (LG VII) to 285 (LG III). LG IV was the longest group (165.12 $\mathrm{cM}$ ), whereas LG VII was the shortest group, spanning $55.7 \mathrm{cM}$ (excluding the minor LGs). Among all major LGs, LG III contained the highest marker density $(1$ marker/0.28 cM) and LG VII the lowest (1 marker/0.68 cM), followed by LG IV (1 marker/0.59 cM). In general, the marker density obtained for each LG was similar (excluding minor LGs). Inspection of $\chi^{2}$ values for goodness of fit for each LG gave insights into the reliability of the obtained map. The $\chi^{2}$ values for all the LGs were $<1$. Details on the nine LGs obtained are presented in Table 1 and Supplementary File S3.

Macrosynteny between $L$. cicera $L G s$ and $P$. sativum chromosomes. After the rearrangement of $L$. cicera $\mathrm{LG}$ order according to the $P$. sativum reference genome v1a, a clear macrosynteny between both species was observed (Fig. 2). However, for about $36 \%$ of the markers mapped on L. cicera linkage, no physical position was found in the pea genome. Furthermore, some cases of nonsyntenic marker order between $L$. cicera linkage map and the pea genome were also observed, meaning that there were different marker order positions between both species. In both cases, those markers mostly correspond to DArT markers, for which the length of the available nucleotide sequence is smaller than $70 \mathrm{pb}$. The macrosynteny between $L$. cicera and $P$. sativum became most clear when DArT markers were removed from analysis (Fig. 2B). The best evidence of nonsyntenic regions was observed in the position of some markers mapped on the upper part of chickling pea LG VI, showing an inverted location in the pea chr3LG5 (Fig. 2C). The correspondence between all $L$. cicera LGs with pseudomolecules of $P$. sativum genome, also incorporating the existing synteny information between $L$. cicera and M. truncatula genome Mt version 4.0 retrieved from the first syntenic analysis between $L$. cicera and M. truncatula (Santos et al. 2018), is presented in Supplementary File S4.

By exploring the homologous region of major and minor LGs, we observed that LG VIII and LG VI were both syntenic with chr3LG5 pea pseudomolecule (Fig. 2C, Supplementary File S4). Additionally, LG IX and LG VII were both syntenic to pea genome chr4LG4 (Fig. 2D, Supplementary File S4).

QTLs for $E$. pisi and $E$. trifolii disease response. Because no significant differences were found between inoculation repetitions ( $P=0.180$ and $P=0.824$ for $E$. pisi and E. trifolii, respectively), a univariate QTL analysis was carried out using the DS averages obtained across repetitions.

Different significant QTLs were identified for either E. pisi or E. trifolii response in the L. cicera RIL population. Three genomic regions associated with response to $E$. pisi were mapped on LG I, II, and IV (EpDSI, EpDSII, and EpDSIV), whereas one QTL for E. trifolii response was mapped in LG VIII (EtDSVIII), one of the minor L. cicera LGs (Fig. 3). EpDSI, EpDSII, and EpDSIV QTLs explained, respectively, $13.0,10.6$, and $8.2 \%$ of the phenotypic variance observed. EtDSVIII QTL explained $16 \%$ of the phenotypic variance observed. Resistant alleles (the ones that contributed to a reduction in DS values) were derived from the partial resistant genotype (BGE023542) in all detected QTLs for both pathogens. The largest QTL interval (1-LOD confidence interval) corresponded to the EtDSVIII QTL and was located in LG VIII with about $2.87 \mathrm{cM}$. The remaining QTLs identified in this study showed confidence intervals smaller than $1.3 \mathrm{cM}$ (Table 2). The strongest QTL (based on LOD score) was the EpDSI (at LG I), with the silicoDArT 100000647 peak marker, showing the highest LOD score (5.11). For each detected QTL, besides the flanking markers, no other marker was found within QTL intervals.

Candidate resistance genes against $E$. pisi and $E$. trifolii. Potential resistance gene candidates within the identified QTL intervals were revealed using BLASTn of nucleotide sequences of QTL flanking markers and by comparative mapping of QTL intervals with the pea reference genome.

Considering the candidate resistance genes associated with the QTL flanking markers of E. pisi resistance QTLs, two

Table 1. Description of the obtained linkage groups of the high-density Lathyrus cicera map. Minor groups are italicized.

\begin{tabular}{lccccc}
\hline Linkage group & Number of loci & $\boldsymbol{\chi}^{\mathbf{2}}$ mean & Length $(\mathbf{c M})$ & Average density $(\mathbf{c M} / \mathbf{m a r k e r})$ & Largest gap $(\mathbf{c M})$ \\
\hline I & 232 & 0.84 & 91.06 & 0.39 & 5.49 \\
II & 245 & 0.37 & 121.31 & 0.50 & 0.28 \\
III & 285 & 0.42 & 80.55 & 0.59 & 6.24 \\
IV & 279 & 0.74 & 165.12 & 0.46 & 1.21 \\
V & 164 & 0.28 & 75.98 & 0.55 & 9.24 \\
VI & 145 & 0.77 & 80.21 & 0.68 & 1.06 \\
VII & 82 & 0.72 & 55.66 & 1.32 & 3.05 \\
VIII & 19 & 0.26 & 20.05 & - & 3.77 \\
IX & 17 & 0.1 & 22.41 & $\mathbf{0 . 6 5}$ & $\mathbf{7 2 . 8 8}$ \\
Total & $\mathbf{1 . 4 6 8}$ & - & $\mathbf{7 1 2 . 3 5}$ & $\mathbf{7 . 9 5 5}$ \\
Average & $\mathbf{1 6 3}$ & $\mathbf{0 . 5 3}$ & $\mathbf{7 9 . 5 5}$ & &
\end{tabular}


candidate genes were identified: translocon at the outer membrane of chloroplasts 64 (TOC64) for EpDSI and Kunitz-type trypsin inhibitor-like 1 protein (KTI1) for EpDSII (Table 3). TOC64 putative function is related to the recognition of HSP90 proteins involved in biotic stress (Qbadou et al. 2006) (Table 3). KTI1 is a protease inhibitor, also described as a modulator of programmed cell death (PCD) in plant-pathogen interactions (Huang et al. 2010; Li et al. 2008) (Table 3). On the other hand, two candidate genes were identified for the response against $E$. trifolii: a regulator of G-protein signaling 1-like (RGS1) and a pentatricopeptide repeat (PPR)-containing protein (Table 3). Diverse cellular processes have been described for RGS1 function, including the plant immune response, by interacting with some receptor-like kinases (RLKs) (Zhang et al. 2012). The PPR-containing proteins are involved in an organelle-nucleus signaling pathway and also involved in various biotic and abiotic stresses (Koussevitzky et al. 2007; Laluk et al. 2011; Lurin et al. 2004; Xing et al. 2018) (Table 3).

In regard to the candidate genes identified by comparative mapping with $P$. sativum genome, the physical position of the QTL flanking markers in the pea genome was inferred to identify syntenic regions between species (Supplementary File S5).

For the EtDSVIII QTL, no syntenic region was identified in the pea genome by comparative mapping, because the c7_a42521 flanking marker was located in a scaffold, not assigned to any pea chromosome (Supplementary File S5). For the other L. cicera QTL intervals (for E. pisi), candidate resistance genes identified based on comparative mapping are listed in Supplementary File S6. Among all candidate genes found in homologous pea genome regions, some genes or gene families are known to be involved in host-pathogen interactions (Supplementary File S6).

\section{Discussion}

Powdery mildew fungi, due to their quick and effective air dispersal and the coexistence of sexual and asexual reproduction cycles, are among the pathogens with the highest risk for breaking down the effectiveness of resistance genes (McDonald and Linde 2002). Partial resistance, in this context, is a potentially more durable approach than complete resistance, due to the reduced selective pressure imposed on the pathogen (McDonald and Linde 2002; Niks and Rubiales 2002). In the present study, a L. cicera RIL population was used to clarify the genetic basis and the putative molecular strategies of powdery mildews' partial resistance, through QTL mapping of $L$. cicera response against both E. pisi and E. trifolii.

All scored individuals showed a compatible reaction to both pathogens, characterized by well-developed colonies on the leaf surface (IT $=4)$, but with noncorrelated DS assessments. This noncorrelated quantitative response led to the identification of different QTLs and candidate resistance genes for partial resistance (high IT, low DS) against either E. pisi or E. trifolii pathogens. The detected QTLs explained small percentages of the total phenotypic variation and were mapped on different LGs, confirming that partial resistance against each of these powdery mildew pathogens is under a different oligogenic control in L. cicera. Moreover, in all detected QTLs for both pathogens, resistant alleles were derived from the partial resistant parental genotype, which is in accordance with the almost absent transgressive segregation observed in the RILs phenotypic
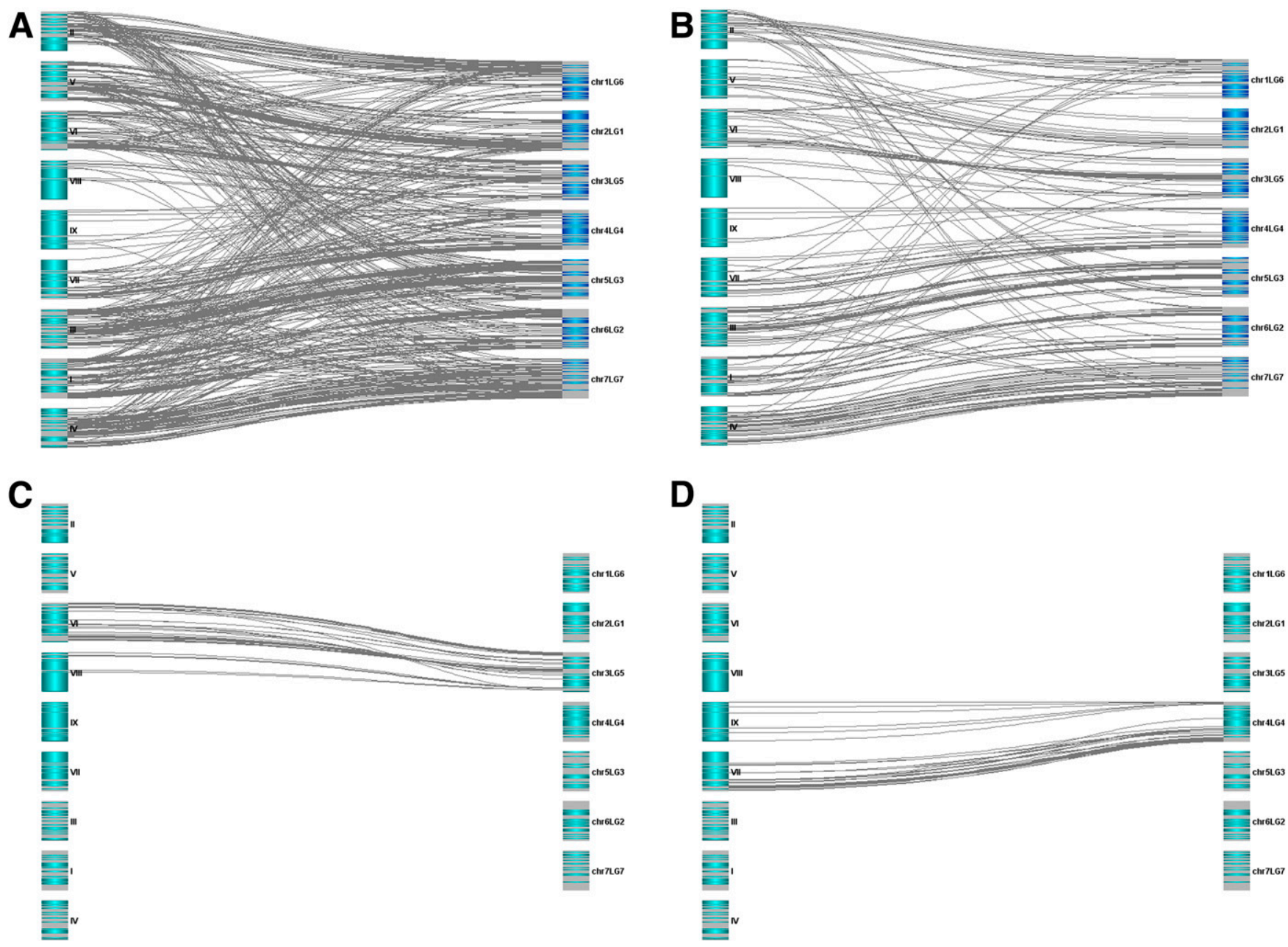

Fig. 2. Comparative plot of rearrangement and syntenic relationships between Lathyrus cicera linkage groups (on the right) and Pisum sativum pseudomolecules v1a (on the left). A, Comparative plot including all markers under study; B, comparative plot excluding DArT markers; C, comparative plot showing P. sativum pseudomolecule chr3LG5 correspondence with L. cicera LGs VI and VIII; and D, P. sativum pseudomolecule chr4LG4 correspondence with L. cicera LGs VII and IX. 
characterization. Partial resistance to $E$. pisi had already been identified in Lathyrus spp. (Vaz Patto et al. 2006a, 2007). However, in $P$. sativum and its wild relatives, few single genes, either recessive (erl and er2) or dominant (Er3), confer resistance to E. pisi (Fondevilla et al. 2006), in addition to few uncharacterized sources of incomplete resistance (Fondevilla and Rubiales 2012; Fondevilla et al. 2007a). Single dominant resistance genes against $E$. pisi have also been suggested in Lathyrus odoratus $\times$ L. belinensis hybrid plants (Poulter et al. 2003). Although the present study pointed to an oligogenic resistance against powdery mildew in L. cicera, we cannot rule out the possibility of identifying monogenic resistance in different $L$. cicera germplasm.

Besides the noncorrelation of the DS assessment, the RILs' average percentages of DS caused by inoculation with E. pisi and E. trifolii were different. About half of the DS average was obtained when leaves were inoculated with E. trifolii (13.8\%) compared with E. pisi (23.2\%). These diverse responses of the L. cicera RIL population may also be explained by differences in the resistance genetic makeup of the RIL population against each powdery mildew pathogen, but it may also be caused by virulence differences of the E. pisi and $E$. trifolii isolates used in this study. Although the existence of different virulent races among $E$. pisi and E. trifolii isolates has not been described unambiguously so far, the existence of different resistance genes against $E$. pisi and/or the effectiveness of resistance depending on environment might suggest the existence of races in this pathogen (Fondevilla and Rubiales 2012). Nevertheless, the double inoculum density used for inoculation with E. pisi (20 conidia/ $\mathrm{mm}^{2}$ ) compared with the 10 conidia/ $/ \mathrm{mm}^{2}$ for E. trifolii could also contribute to these DS differences.

Considering, specifically, the genes identified underlying the QTL interval flanking markers, KTI proteins may have an important role on $L$. cicera response to $E$. pisi, by secretion of antifungal compounds and/or modulation of PCD, and TOC64 may be involved in the signal integration during pathogen recognition for a plant innate response. However, L. cicera partial resistance to E. trifolii may be more related to a specific pathogen recognition through RGS1 and by the still-unknown action of PPR proteins. In addition to those genes found through the QTL interval flanking markers, a set of genes/gene families described as involved in host-pathogen interactions were identified in the pea syntenic regions of EpDSI,

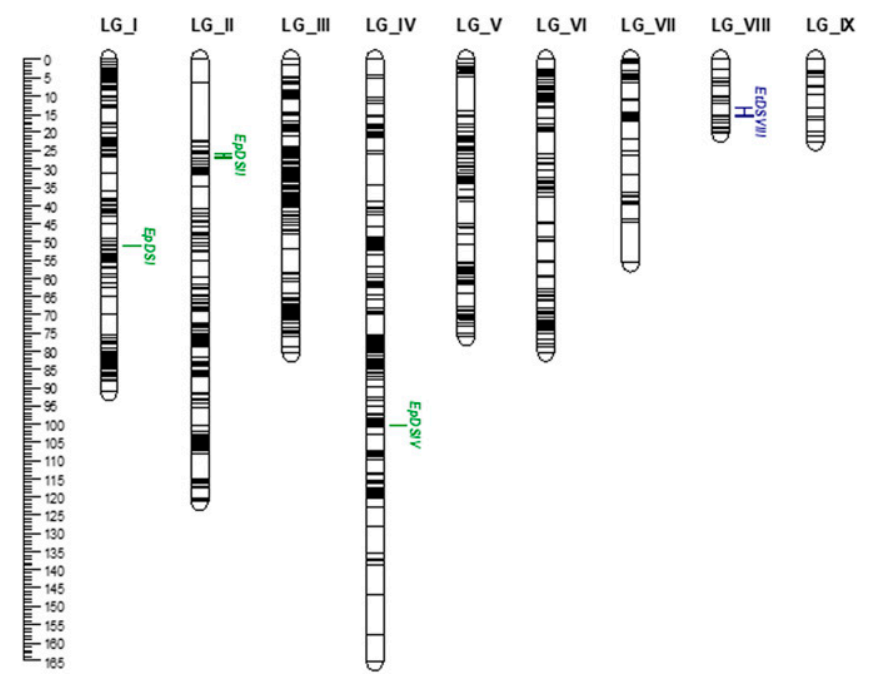

Fig. 3. Quantitative trait loci (QTLs) for powdery mildew (Erysiphe pisi and E. trifolii) response mapped on the high-density Lathyrus cicera genetic linkage map based on a recombinant inbred lines population (BGE023542 × BGE008277). Genetic distances given in centimorgans (Kosambi mapping function) are indicated by the ruler at the left. Horizontal black lines indicate marker positions along linkage groups (LGs). Boxes, extended by lines representing the 1-LOD confidence interval, represent QTL intervals for EpDS (disease severity [\%] for E. pisi; LGs I, II, and IV) and EtDS (disease severity [\%] for E. trifolii; LG VIII).
EpDSII, and EpDSIV. Integrating both approaches of identification of candidate resistance genes against $E$. pisi, a more detailed description of $L$. cicera layers of resistance to this pathogen could be proposed. Accordingly, during the first host-pathogen contact, the previously mentioned KTI proteins may be involved in the development of a chemical barrier, because KTI is a predicted secreted protein that has antifungal activity (Huang et al. 2010). Because it is an antifungal protein, the isolation and purification of KTI1 may have a biotechnological application (Yan et al. 2015), such as the development of phytopharmaceutical products against powdery mildew. Moreover, cellulose synthase and the glycosyl hydrolase family 1 genes, found within the pea EpDSII QTL syntenic region, may also contribute to the development of physical barriers in this first line of defense by cell wall reinforcement with cellulose appositions limiting pathogen penetration (Douchkov et al. 2016; Voigt 2016), and/ or by hydrolyzation of fungal cell wall components (glucans) (Ebrahim et al. 2011; Giannakis et al. 2008), respectively. This mechanism resembles the erl (PsMLO1) functions, because loss of function of MLO1 in pea is associated with protein cross-linking in host cell walls, acting as an effective physical barrier to avoid penetration by the pathogen (Iglesias-García et al. 2015).

In the case in which the pathogen overcomes those chemical and physical barriers, pathogen associated molecular patterns (PAMPs) and/or effectors specifically recognized by the host may activate another layer of defense response: PAMPs-triggered immunity or effector-triggered immunity, respectively (Jones and Dangl 2006; Stael et al. 2015). At this stage, transmembrane protein complex leucine-rich repeats (LRRs)-protein kinases and cytoplasmic protein complex containing LRR, nucleotide-binding, and toll interleukin 1 receptor (TIR) motifs, like the ones found in the pea EpDSII and/or EpDSIV QTL syntenic regions, may have an important role in signaling pathogen recognition (Gururani et al. 2012; Swiderski et al. 2009). Subsequently, other plant defense mechanisms are triggered, including the activation of transcription factors and systemic responses. The ethylene response factor (ERF) transcription factors, LSD1 zinc finger and really interesting new gene (RING) finger domains, identified as underlying the pea QTL syntenic regions for $E$. pisi resistance, may eventually become involved at this stage in defense response signaling. ERFs are transcriptionally regulated by pathogens, ethylene (ET), and jasmonic acid (JA) phytohormones, integrating JA- and ET-dependent defense signals and conferring enhanced disease resistance (Gutterson and Reuber 2004).

Additionally, the recognition of HSP90 proteins by TOC64 (the candidate resistance gene underlying a $E p D S I$ QTL flanking marker) may be also involved in L. cicera signaling regulation against $E$. pisi (Qbadou et al. 2006, 2007; Sohrt and Soll 2000). TOC64 is a chaperone receptor, acting on both sides of the chloroplast membrane, mediating HSP90-dependent protein targeting to chloroplasts (Qbadou et al. 2006). HSP90 and HSC70/HSP90 machinery contribute to plant innate response and serve essential functions in plants to integrate signals from both biotic and abiotic environments (Clément et al. 2011). In pea, after inoculation with E. pisi, HSP70 proteins were identified to be involved in stress and defense response (Curto et al. 2006).

Finally, if all previous defense responses fail to inhibit pathogen penetration and colonization, cells under attack can undergo PCD. PCD is an integral component of plant immunity (Muthamilarasan and Prasad 2013; Zhang et al. 2012), preventing pathogen colonization and spread, acting as the last layer of defense (Mur et al. 2008; Muthamilarasan and Prasad 2013; Zhang et al. 2012). In this stage, KTI proteins (the gene identified as underlying the peak marker on EpDSI QTL) may also modulate PCD in L. cicera, as already described for other pathogens in Arabidopsis (Li et al. 2008). Moreover, the LSD1 zinc finger and RING proteins (found within the pea EpDSII and EpDSIV QTL syntenic regions) may also be involved in PCD during $L$. cicera infection by E. pisi. The LSD1 zinc finger negatively regulates $\mathrm{PCD}$ and plant defense signaling pathways (Dietrich et al. 1997; Wang et al. 2005), whereas the majority of RING proteins are believed to act as E3 ubiquitin ligases (Jiménez-López et al. 2018; Nakamura 2011). Several genes encoding RING-type E3 
ubiquitin ligases have been predicted to regulate abscisic acid signaling and pathogen response, because they can target defense regulatory proteins for ubiquitination to control downstream signaling pathways (Devoto et al. 2003; Jiménez-López et al. 2018). Therefore, although no HR was observed macroscopically in this study, which is in agreement with previous phenotypic studies in Lathyrus spp. inoculated with E. pisi (Vaz Patto et al. 2006a, 2007), we cannot exclude the contribution of a very early acting PCD in L. cicera in causing the early abortion of some infection units or even the reduction of colony growth, not detected macroscopically in response to powdery mildew infection. Indeed, HR is an effective mechanism against biotrophic pathogens, including powdery mildew in legumes (Rubiales et al. 2015; Zhang et al. 2013), as observed macro- and microscopically for Pisum species (Fondevilla and Rubiales 2012; Fondevilla et al. 2006, 2007a) and M. truncatula (Prats et al. 2007). Therefore, detailed histological studies are still needed to investigate the role of $\mathrm{HR}$ in the L. cicera response against powdery mildew infection.

Comparing the candidate resistance genes to E. pisi identified here with the resistance genes and proteins previously studied in pea (Barilli et al. 2014; Curto et al. 2006; Fondevilla et al. 2006, 2007b; Iglesias-García et al. 2015), common pathways seemed to be involved in the response of both legume species against this pathogen: antifungal activity, reinforcement of cell walls, specific recognition of the pathogen that triggers downstream host defense signaling, and pathogenesis-related proteins activation.

Regarding the specific response of L. cicera against E. trifolii infection, a regulator of G-protein signaling 1-like (RGS1) was identified as a candidate resistance gene using the QTL flanking markers. Plant RGS proteins have a seven-transmembrane containing receptors domain. They are predicted to interact with some RLKs usually involved in the pathogen recognition, regulating the activation state of $\mathrm{G}$ protein complex (Lu et al. 2009; Urano et al. 2013). G proteins play a key regulatory role in multiple physiological processes, including the plant immune response, by transducing extracellular signals from cell surface receptors into intracellular effectors, triggering the defensesignaling network and PCD (Zhang et al. 2012). Beyond the putative role of RGS1 in L. cicera against E. trifolii, in a proteomic study (Curto et al. 2006), a $G$ protein beta subunit-like seemed also to be involved in pea resistance to $E$. pisi, because it was detected in resistant genotype (carrying er2) and not detected in a susceptible genotype.

In addition, members of the PPR-containing protein family, identified as a candidate resistance gene family for $E$. trifolii, were also found in pea EpDSII and EPDSIV QTL syntenic regions. PPR proteins have been identified as playing important roles in organellar RNA metabolism, organ development, and, more recently, in various biotic and abiotic stresses (Koussevitzky et al. 2007; Laluk et al. 2011; Lurin et al. 2004; Xing et al. 2018). Although the function

Table 2. Description of quantitative trait loci (QTLs) identified for resistance against Erysiphe pisi and E. trifolii in the Lathyrus cicera recombinant inbred lines (RILs) population (BGE023542 $\times$ BGE008277)

\begin{tabular}{|c|c|c|c|c|c|c|c|}
\hline Trait name ${ }^{a}$ & QTL $^{\mathbf{b}}$ & $\mathbf{L G}^{\mathbf{c}}$ & Peak QTL position (cM) & QTL interval $(\mathrm{cM})^{\mathrm{d}}$ & LOD $^{\mathbf{e}}$ & $R^{2}(\%)^{\mathbf{f}}$ & Additive effect \\
\hline E. pisi DS & EpDSI & I & 51.3 & - & 5.11 & 13.0 & -2.52 \\
\hline E. pisi DS & EpDSII & II & 27.0 & $25.74-27.0$ & 3.51 & 10.6 & -2.08 \\
\hline E. pisi DS & EpDSIV & IV & 100.13 & $100.13-100.16$ & 4.26 & 8.2 & -2.08 \\
\hline E. trifolii DS & EtDSVIII & VIII & 15.8 & $12.98-15.85$ & 3.89 & 16 & -1.98 \\
\hline
\end{tabular}

${ }^{a}$ E. pisi and E. trifolii DS = disease severity (\%) assessed after E. pisi and E. trifolii inoculations, respectively, in leaflets of L. cicera RILs, under controlled conditions.

b Nomenclature assigned to QTLs identified.

${ }^{\mathrm{c}} \mathrm{LG}=$ linkage group.

${ }^{\mathrm{d}}$ QTL interval including 1-LOD confidence support.

${ }^{\mathrm{e}} \mathrm{LOD}=$ the peak LOD score.

${ }^{\mathrm{f}} R^{2}=$ proportion of phenotypic variance explained by the respective QTL (\%).

$\mathrm{g}$ Additive effect $=($ mu_BGE023542 - mu_BGE008277) $/ 2$; negative values indicate that the BGE023542 allele increased resistance trait value; mu_BGE023542 = the estimated average of the distribution of the quantitative trait associated with the BGE023542 allele; and mu_BGE008277 = idem for the BGE008277 allele.

Table 3. Molecular markers associated to quantitative trait loci (QTLs) EpDSI, EpDSII, EpDSIV, and EtDSVIII and the respective candidate genes identified using BLASTn tools

\begin{tabular}{|c|c|c|c|c|c|c|}
\hline QTL & $\begin{array}{l}\text { Marker } \\
\text { underlying } \\
\text { QTL }\end{array}$ & $\begin{array}{c}\text { Marker } \\
\text { type }^{\mathbf{a}}\end{array}$ & $\begin{array}{l}\text { BLAST hit } \\
\text { [species] }\end{array}$ & $\begin{array}{l}\text { BLAST } \\
\text { e-value }\end{array}$ & Functions & References \\
\hline$\overline{E p D S I}$ & 100000647 & SilicoDArT & $\begin{array}{l}\text { Translocon at the outer } \\
\text { membrane of chloroplasts } 64 \\
\text { (TOC64) [Vigna radiata] }\end{array}$ & $1 \mathrm{e}^{-05}$ & $\begin{array}{l}\text { Chaperone receptor mediating } \\
\text { HSP90-dependent protein } \\
\text { targeting to chloroplasts. }\end{array}$ & $\begin{array}{l}\text { Clément et al. (2011); Qbadou } \\
\text { et al. (2006, 2007); Sohrt and } \\
\text { Soll (2000) }\end{array}$ \\
\hline \multirow[t]{2}{*}{ EpDSII } & c6_a1049 & SNP & $\begin{array}{l}\text { Kunitz-type trypsin inhibitor- } \\
\text { like } 1 \text { protein (KTI1) [Medicago } \\
\text { truncatula] }\end{array}$ & $1 \mathrm{e}^{-143}$ & $\begin{array}{l}\text { Protease inhibitor activity. } \\
\text { Antifungal activity. Modulator } \\
\text { of programmed cell death in } \\
\text { plant-pathogen interactions. }\end{array}$ & $\begin{array}{l}\text { Huang et al. (2010); Li et al. } \\
\text { (2008) }\end{array}$ \\
\hline & 100000429 & SilicoDArT & No hits & - & - & - \\
\hline \multirow[t]{2}{*}{ EpDSIV } & 100000495 & SilicoDArT & No hits & - & - & - \\
\hline & 100004040 & SilicoDArT & No hits & - & - & - \\
\hline \multirow[t]{2}{*}{ EtDSVIII } & 100000552 & SilicoDArT & $\begin{array}{l}\text { Regulator of G-protein } \\
\text { signaling 1-like (RGS1) } \\
\text { [Glycine soja] }\end{array}$ & $8 \mathrm{e}^{-08}$ & $\begin{array}{l}\text { Predicted to interact with some } \\
\text { receptor-like kinases (RLKs). } \\
\text { Involved in stress signal } \\
\text { transduction. }\end{array}$ & $\begin{array}{l}\text { Lu et al. (2009); Urano et al. } \\
\text { (2013); Zhang et al. (2012) }\end{array}$ \\
\hline & c7_a42521 & SNP & $\begin{array}{l}\text { Pentatricopeptide repeat (PPR)- } \\
\text { containing protein [Medicago } \\
\text { truncatula] }\end{array}$ & 0.0 & $\begin{array}{l}\text { Chloroplast-nucleus signaling } \\
\text { pathway involved in various } \\
\text { biotic and abiotic stresses. }\end{array}$ & $\begin{array}{l}\text { Koussevitzky et al. (2007); } \\
\text { Laluk et al. (2011); Lurin et al. } \\
\text { (2004); Xing et al. (2018) }\end{array}$ \\
\hline
\end{tabular}

a Diversity arrays technology (DArT) combined with next-generation sequencing platforms (DArTseq) genotyping generates two types of markers: silicoDArT
and single nucleotide polymorphism (SNP) markers. SilicoDArT markers are microarray markers that are dominant and scored for the presence or absence of a single allele, whereas DArTseq-based SNPs are codominant markers. 
of PPR proteins has been reported for necrotrophic fungi and pathogenic bacteria and fungi (Laluk et al. 2011; Park et al. 2014), no putative role in powdery mildew response has been reported thus far. Therefore, genes encoding for members of the PPR gene family and $\mathrm{G}$ protein complex should be further investigated to explore their function on legume response to both powdery mildew pathogens. Despite the identification of distinct QTLs for each powdery mildew pathogen response in L. cicera, some resistance genes or pathways may be common in response to both E. pisi and E. trifolii, for instance, through the involvement of a PPR gene family and G protein complex. The identification of common resistance genes effective against both powdery mildew pathogens may be useful for the development of multiple powdery mildew resistant cultivars.

QTLs for partial resistance to powdery mildew pathogens were detected on the newly developed high-density $L$. cicera linkage map, integrating different types of markers, confirming the usefulness of this new chickling pea genetic tool. This genetic linkage map can now be used more efficiently for other QTL analyses of traits segregating in this RIL population, such as rust resistance (Santos et al. 2018). The 1,468 markers were distributed along seven major LGs (as expected for L. cicera, $2 \mathrm{n}=14$ ) and two minor LGs. The QTL for E. trifolii response was mapped in one of the L. cicera minor LGs (LG VIII, EtDSVIII QTL) that should eventually merge with the distal part of LG VI, as previously suggested by syntenic analysis with M. truncatula (Santos et al. 2018) and here confirmed by the syntenic analysis with the $P$. sativum genome vla. Moreover, the syntenic analysis with the pea genome also allowed the clarification of the most probable position of L. cicera minor LG IX as the upper part of LG VII and not on LG IV, as previously suggested by a syntenic analysis with $M$. truncatula (Santos et al. 2018). Indeed, the $M$. truncatula genome evolved from the ancestral Galegoid karyotype through two fissions, two fusions, and one translocation between chromosome 4 and 8, which did not occur in pea (Kamphuis et al. 2007; Kreplak et al. 2019). Consequently, both chr4LG4 and chr7LG7 of $P$. sativum span chromosome portions of 4 and 8 of M. truncatula (Kreplak et al. 2019). Similar genome evolution may have occurred in Lathyrus genera, given the phylogenetically proximity to Pisum spp.

Although the higher number of markers was mapped in the new version of the L. cicera map, the total length of both maps was similar: $712.35 \mathrm{cM}$ and $724.4 \mathrm{cM}$ in the new and previous versions, respectively. Consequently, the marker density in the new map $(0.65$ $\mathrm{cM} /$ marker) was five times higher than what was reported in the previous one, in which an average mapping interval of $2.4 \mathrm{cM}$ was obtained (Santos et al. 2018). Nevertheless, more efforts should be implemented in the future in order to reach the seven LGs expected for Lathyrus spp. This might be attained by increasing the number of individuals in the segregating population or the number of markers screened, or by using common markers scored in different Lathyrus populations to construct a consensus genetic linkage map.

In summary, different QTLs and candidate genes for either E. pisi or E. trifolii partial resistance were identified in a L. cicera RIL population. Based on candidate genes underlying the QTLs' flanking markers, L. cicera partial resistance to E. pisi may involve the secretion of antifungal compounds and signaling integration during infection, whereas specific pathogen recognition may have a central role in $L$. cicera response against $E$. trifolii. Because powdery mildews are among the pathogens with the highest risk of breaking down the effectiveness of resistance genes (McDonald and Linde 2002), partial resistance should be considered for the development of durable resistant cultivars of grain legume species (Vaz Patto et al. 2006a). A list of candidate resistant genes to powdery mildew was provided; however, the putative resistance conferred by those genes should be validated with further research. This could be accomplished by transcript profiling and/or functional analysis using Lathyrus spp. and/or $M$. truncatula as a model to study powdery mildew resistance (Rispail et al. 2019). Nevertheless, the flanking markers of QTLs for resistance against E. pisi and E. trifolii may already support a more efficient marker assisted selection in chickling pea.

\section{Acknowledgments}

We thank the CRF-INIA, Madrid, Spain, for supplying the parental genotypes. We also acknowledge Sara Fondevilla for assisting with maintenance and multiplication of E. pisi and E. trifolii isolates, and María José González-Bernal and Nuno Almeida for technical support.

\section{Literature Cited}

Ahmad, N. S., Redjeki, E. S., Ho, W. K., Aliyu, S., Mayes, K., Massawe, F., Kilian, A., and Mayes, S. 2016. Construction of a genetic linkage map and QTL analysis in bambara groundnut. Genome 59:459-472.

Alam, M., Neal, J., O'Connor, K., Kilian, A., and Topp, B. 2018. Ultra-highthroughput DArTseq-based silicoDArT and SNP markers for genomic studies in macadamia. PLoS One 13:e0203465.

Ates, D., Aldemir, S., Alsaleh, A., Erdogmus, S., Nemli, S., Kahriman, A., Ozkan, H., Vandenberg, A., and Tanyolac, B. 2018. A consensus linkage map of lentil based on DArT markers from three RIL mapping populations. PLoS One 13: e0191375.

Attanayake, R. N., Dugan, F. M., Chen, W., Glawe, D. A., and McPhee, K. E. 2010b. Potential alternative hosts for the pea powdery mildew pathogen Erysiphe trifolii. Pisum Genet. 42:18-20.

Attanayake, R. N., Glawe, D. A., McPhee, K. E., Dugan, F. M., and Chen, W. 2010a. Erysiphe trifolii-A newly recognized powdery mildew pathogen of pea. Plant Pathol. 59:712-720.

Aznar-Fernández, T., Barilli, E., Cobos, M. J., Kilian, A., Carling, J., and Rubiales, D. 2020. Identification of quantitative trait loci (QTL) controlling resistance to pea weevil (Bruchus pisorum) in a high-density integrated DArTseq SNP-based genetic map of pea. Sci. Rep. 10:33

Barilli, E., Cobos, M. J., Carrillo, E., Kilian, A., Carling, J., and Rubiales, D. 2018. A high-density integrated DArTseq SNP-based genetic map of Pisum fulvum and identification of QTLs controlling rust resistance. Front. Plant Sci. 9:167.

Barilli, E., Rubiales, D., Gjetting, T., and Lyngkjaer, M. F. 2014. Differential gene transcript accumulation in peas in response to powdery mildew (Erysiphe pisi) attack. Euphytica 198:13-28.

Bayer, M., Milne, I., Stephen, G., Shaw, P., Cardle, L., Wright, F., and Marshall, D. 2011. Comparative visualization of genetic and physical maps with strudel. Bioinformatics 27:1307-1308.

Braun, U. 1987. A monograph of the Erysiphales (powdery mildews). Beih. zur Nov. Hedwigia 89:1-700.

Briñez, B., Blair, M. W., Kilian, A., Carbonell, S. A. M., Chiorato, A. F., and Rubiano, L. B. 2012. A whole genome DArT assay to assess germplasm collection diversity in common beans. Mol. Breed. 30:181-193.

Clément, M., Leonhardt, N., Droillard, M.-J., Reiter, I., Montillet, J.-L., Genty, B., Laurière, C., Nussaume, L., and Noël, L. D. 2011. The cytosolic/nuclear HSC70 and HSP90 molecular chaperones are important for stomatal closure and modulate abscisic acid-dependent physiological responses in Arabidopsis. Plant Physiol. 156:1481-1492.

Curto, M., Camafeita, E., Lopez, J. A., Maldonado, A. M., Rubiales, D., and Jorrín, J. V. 2006. A proteomic approach to study pea (Pisum sativum) responses to powdery mildew (Erysiphe pisi). Proteomics 6 (S1):S163-S174.

Devoto, A., Muskett, P. R., and Shirasu, K. 2003. Role of ubiquitination in the regulation of plant defence against pathogens. Curr. Opin. Plant Biol. 6: 307-311.

Dietrich, R. A., Richberg, M. H., Schmidt, R., Dean, C., and Dangl, J. L. 1997. A novel zinc finger protein is encoded by the Arabidopsis LSD1 gene and functions as a negative regulator of plant cell death. Cell 88:685-694.

Douchkov, D., Lueck, S., Hensel, G., Kumlehn, J., Rajaraman, J., Johrde, A., Doblin, M. S., Beahan, C. T., Kopischke, M., Fuchs, R., Lipka, V., Niks, R. E., Bulone, V., Chowdhury, J., Little, A., Burton, R. A., Bacic, A., Fincher, G. B., and Schweizer, P. 2016. The barley (Hordeum vulgare) cellulose synthase-like D2 gene ( $\mathrm{HvCslD2})$ mediates penetration resistance to host-adapted and nonhost isolates of the powdery mildew fungus. New Phytol. 212:421-433

Ebrahim, S., Usha, K., and Singh, B. 2011. Pathogenesis related (PR) proteins in plant defense mechanism age-related pathogen resistance. Curr Res Technol Adv. 2:1043-1054.

Fondevilla, S., Carver, T. L. W., Moreno, M. T., and Rubiales, D. 2006. Macroscopic and histological characterisation of genes erl and er2 for powdery mildew resistance in pea. Eur. J. Plant Pathol. 115:309-321.

Fondevilla, S., Carver, T. L. W., Moreno, M. T., and Rubiales, D. 2007a Identification and characterization of sources of resistance to Erysiphe pisi Syd. in Pisum spp. Plant Breed. 126:113-119.

Fondevilla, S., Chattopadhyay, C., Khare, N., and Rubiales, D. 2013. Erysiphe trifolii is able to overcome erl and Er3, but not er2, resistance genes in pea Eur. J. Plant Pathol. 136:557-563.

Fondevilla, S., Cubero, J. I., and Rubiales, D. 2011. Confirmation that the Er3 gene, conferring resistance to Erysiphe pisi in pea, is a different gene from erl and er2 genes. Plant Breed. 130:281-282.

Fondevilla, S., and Rubiales, D. 2012. Powdery mildew control in pea: A review. Agron. Sustain. Dev. 32:401-409.

Fondevilla, S., Torres, A., Moreno, M., and Rubiales, D. 2007b. Identification of a new gene for resistance to powdery mildew in Pisum fulvum, a wild relative of pea. Breed. Sci. 57:181-184. 
Giannakis, C., Bucheli, C. S., Skene, K. G. M., Robinson, S. P., and Scott, N. S. 2008. Chitinase and $\beta$-1,3-glucanase in grapevine leaves: A possible defence against powdery mildew infection. Aust. J. Grape Wine Res. 4:14-22.

Gururani, M. A., Venkatesh, J., Upadhyaya, C. P., Nookaraju, A., Pandey, S. K., and Park, S. W. 2012. Plant disease resistance genes: Current status and future directions. Physiol. Mol. Plant Pathol. 78:51-65.

Gutterson, N., and Reuber, T. L. 2004. Regulation of disease resistance pathways by AP2/ERF transcription factors. Curr. Opin. Plant Biol. 7:465-471.

Hammer, K., Laghetti, G., Direnzo, P., Castelli, A., and Mikić, A. 2019. Resources and opportunities for re-establishing Lathyrus cicera L. as a multipurpose cultivated plant. Genet. Resour. Crop Evol. 66:523-544.

Hanbury, C., White, C., Mullan, B., and Siddique, K. H. 2000. A review of the potential of Lathyrus sativus L. and L. cicera L. grain for use as animal feed. Anim. Feed Sci. Technol. 87:1-27.

Harland, S. C. 1948. Inheritance of immunity to mildew in Peruvian forms of Pisum sativum. Heredity 2:263-269.

Heringa, R. J., van Norel, A., and Tazelaar, M. F. 1969. Resistance to powdery mildew (Erisyphe polygoni D.C.) in peas (Pisum sativum L.). Euphytica 18: 163-169.

Huang, H., Qi, S. D., Qi, F., Wu, C. A., Yang, G. D., and Zheng, C. C. 2010. NtKTI1, a Kunitz trypsin inhibitor with antifungal activity from Nicotiana tabacum, plays an important role in tobacco's defense response. FEBS J. 277:4076-4088.

Humphry, M., Reinstädler, A., Ivanov, S., Bisseling, T., and Panstruga, R. 2011. Durable broad-spectrum powdery mildew resistance in pea erl plants is conferred by natural loss-of-function mutations in PsMLO1. Mol. Plant Pathol. 12:866-878.

Iglesias-García, R., Rubiales, D., and Fondevilla, S. 2015. Penetration resistance to Erysiphe pisi in pea mediated by erl gene is associated with protein crosslinking but not with callose apposition or hypersensitive response. Euphytica 201:381-387.

Jaccoud, D., Peng, K., Feinstein, D., and Kilian, A. 2001. Diversity arrays: A solid state technology for sequence information independent genotyping. Nucleic Acids Res. 29:e25.

Jansen, R. C., and Stam, P. 1994. High resolution of quantitative traits into multiple loci via interval mapping. Genetics 136:1447-1455.

Jiménez-López, D., Muñóz-Belman, F., González-Prieto, J. M., AguilarHernández, V., and Guzmán, P. 2018. Repertoire of plant RING E3 ubiquitin ligases revisited: New groups counting gene families and single genes. PLoS One 13:e0203442.

Jones, J., and Dangl, J. 2006. The plant immune system. Nature 444:323-329.

Kamphuis, L. G., Williams, A. H., D’Souza, N. K., Pfaff, T., Ellwood, S. R., Groves, E. J., Singh, K. B., Oliver, R. P., and Lichtenzveig, J. 2007. The Medicago truncatula reference accession A17 has an aberrant chromosomal configuration. New Phytol. 174:299-303.

Kenicer, G. J., Kajita, T., Pennington, R. T., and Murata, J. 2005. Systematics and biogeography of Lathyrus (Leguminosae) based on internal transcribed spacer and cpDNA sequence data. Am. J. Bot. 92:1199-1209.

Kilian, A., Wenzl, P., Huttner, E., Carling, J., Xia, L., Blois, H., Caig, V., HellerUszynska, K., Jaccoud, D., Hopper, C., Aschenbrenner-Kilian, M., Evers, M., Peng, K., Cayla, C., Hok, P., and Uszynski, G. 2012. Diversity arrays technology: A generic genome profiling technology on open platforms. Methods Mol. Biol. 888:67-89.

Kobes, M., Voženílková, B., Šlachta, M., and Frelich, J. 2011. The occurrence of Erysiphe trifolii on Lathyrus pratensis in a foothill area of South Bohemia. J. Agrobiol. 28:25-31.

Kosambi, D. D. 1943. The estimation of map distances from recombination values. Ann. Eugen. 12:172-175.

Koussevitzky, S., Nott, A., Mockler, T. C., Hong, F., Sachetto-Martins, G., Surpin, M., Lim, J., Mittler, R., and Chory, J. 2007. Signals from chloroplasts converge to regulate nuclear gene expression. Science 316:715-719.

Kreplak, J., Madoui, M.-A., Cápal, P., Novák, P., Labadie, K., Aubert, G., Bayer, P. E., Gali, K. K., Syme, R. A., Main, D., Klein, A., Bérard, A., Vrbová, I., Fournier, C., d'Agata, L., Belser, C., Berrabah, W., Toegelová, H., Milec, Z., Vrána, J., Lee, H., Kougbeadjo, A., Térézol, M., Huneau, C., Turo, C. J., Mohellibi, N., Neumann, P., Falque, M., Gallardo, K., McGee, R., Tar'an, B., Bendahmane, A., Aury, J. M., Batley, J., Le Paslier, M. C., Ellis, N., Warkentin, T. D., Coyne, C. J., Salse, J., Edwards, D., Lichtenzveig, J., Macas, J., Doležel, J., Wincker, P., and Burstin, J. 2019. A reference genome for pea provides insight into legume genome evolution. Nat. Genet. 51: 1411-1422.

Laluk, K., AbuQamar, S., and Mengiste, T. 2011. The Arabidopsis mitochondrialocalized pentatricopeptide repeat protein PGN functions in defense against necrotrophic fungi and abiotic stress tolerance. Plant Physiol. 156:2053-2068.

Lander, E. S., and Botstein, D. 1989. Mapping mendelian factors underlying quantitative traits using RFLP linkage maps. Genetics 121:185-199.

Li, J., Brader, G., and Palva, E. T. 2008. Kunitz trypsin inhibitor: An antagonist of cell death triggered by phytopathogens and fumonisin B1 in Arabidopsis. Mol. Plant 1:482-495.

Lu, G., Wang, Z., Jones, A. M., and Moriyama, E. N. 2009. 7TMRmine: A web server for hierarchical mining of 7TMR proteins. BMC Genomics 10:275.

Lurin, C., Andrés, C., Aubourg, S., Bellaoui, M., Bitton, F., Bruyère, C., Caboche, M., Debast, C., Gualberto, J., Hoffmann, B., Lecharny, A., Le Ret, M., Martin-
Magniette, M. L., Mireau, H., Peeters, N., Renou, J. P., Szurek, B., Taconnat, L., and Small, I. 2004. Genome-wide analysis of Arabidopsis pentatricopeptide repeat proteins reveals their essential role in organelle biogenesis. Plant Cell 16: 2089-2103.

McDonald, B. A., and Linde, C. 2002. Pathogen population genetics, evolutionary potential, and durable resistance. Annu. Rev. Phytopathol. 40:349-379.

Mur, L. A. J., Kenton, P., Lloyd, A. J., Ougham, H., and Prats, E. 2008. The hypersensitive response; the centenary is upon us but how much do we know? J. Exp. Bot. 59:501-520.

Muthamilarasan, M., and Prasad, M. 2013. Plant innate immunity: An updated insight into defense mechanism. J. Biosci. 38:433-449.

Nakamura, N. 2011. The role of the transmembrane RING finger proteins in cellular and organelle function. Membranes (Basel) 1:354-393.

Nelson, R., Wiesner-Hanks, T., Wisser, R., and Balint-Kurti, P. 2017. Navigating complexity to breed disease-resistant crops. Nat. Rev. Genet. 19:21-33.

Niks, R. E., and Rubiales, D. 2002. Potentially durable resistance mechanisms in plants to specialised fungal pathogens. Euphytica 124:201-216.

Oblessuc, P. R., Cardoso Perseguini, J. M. K., Baroni, R. M., Chiorato, A. F., Carbonell, S. A. M., Mondego, J. M. C., Vidal, R. O., Camargo, L. E., and Benchimol-Reis, L. L. 2013. Increasing the density of markers around a major QTL controlling resistance to angular leaf spot in common bean. Theor. Appl. Genet. 126:2451-2465.

Park, Y. J., Lee, H. J., Kwak, K. J., Lee, K., Hong, S. W., and Kang, H. 2014 MicroRNA400-guided cleavage of pentatricopeptide repeat protein mRNAs renders Arabidopsis thaliana more susceptible to pathogenic bacteria and fungi. Plant Cell Physiol. 55:1660-1668.

Peña-Chocarro, L., and Peña, L. Z. 1999. History and traditional cultivation of Lathyrus sativus L. and Lathyrus cicera L. in the Iberian peninsula. Veg. Hist. Archaeobot. 8:49-52.

Poulter, R., Harvey, L., and Burritt, D. J. 2003. Qualitative resistance to powdery mildew in hybrid sweet peas. Euphytica 133:349-358.

Prats, E., Llamas, M. J., and Rubiales, D. 2007. Characterization of resistance mechanisms to Erysiphe pisi in Medicago truncatula. Phytopathology 97: 1049-1053

Qbadou, S., Becker, T., Bionda, T., Reger, K., Ruprecht, M., Soll, J., and Schleiff, E. 2007. Toc64-A preprotein-receptor at the outer membrane with bipartide function. J. Mol. Biol. 367:1330-1346.

Qbadou, S., Becker, T., Mirus, O., Tews, I., Soll, J., and Schleiff, E. 2006. The molecular chaperone Hsp90 delivers precursor proteins to the chloroplast import receptor Toc64. EMBO J. 25:1836-1847.

Rispail, N., Prats, E., and Rubiales, D. 2019. Medicago truncatula as a model to study powdery mildew resistance. Pages 390-397 in: The Model Legume Medicago truncatula. F. de Bruijn, ed. Wiley-Blackwell, Hoboken, NJ.

Rubiales, D., Castillejo, M. A., Madrid, E., Barilli, E., and Rispail, N. 2011 Legume breeding for rust resistance: Lessons to learn from the model Medicago truncatula. Euphytica 180:89-98.

Rubiales, D., Fondevilla, S., Chen, W., Gentzbittel, L., Higgins, T. J. V., Castillejo, M. A., Singh, K. B., and Rispail, N. 2015. Achievements and challenges in legume breeding for pest and disease resistance. Crit. Rev. Plant Sci. 34: 195-236.

Santos, C., Almeida, N. F., Alves, M. L., Horres, R., Krezdorn, N., Leitão, S. T., Aznar-Fernández, T., Rotter, B., Winter, P., Rubiales, D., and Vaz Patto, M. C. 2018. First genetic linkage map of Lathyrus cicera based on RNA sequencingderived markers: Key tool for genetic mapping of disease resistance. Hortic. Res. 5:45.

Sohrt, K., and Soll, J. 2000. Toc64, a new component of the protein translocon of chloroplasts. J. Cell Biol. 148:1213-1222.

Stael, S., Kmiecik, P., Willems, P., van Der Kelen, K., Coll, N. S., Teige, M., and van Breusegem, F. 2015. Plant innate immunity-Sunny side up? Trends Plant Sci. 20:3-11.

Swiderski, M. R., Birker, D., and Jones, J. D. G. 2009. The TIR domain of TIRNB-LRR resistance proteins is a signaling domain involved in cell death induction. Mol. Plant-Microbe Interact. 22:157-165.

Thudi, M., Bohra, A., Nayak, S. N., Varghese, N., Shah, T. M., Penmetsa, R. V., Thirunavukkarasu, N., Gudipati, S., Gaur, P. M., Kulwal, P. L., Upadhyaya, H. D., Kavikishor, P. B., Winter, P., Kahl, G., Town, C. D., Kilian, A., Cook, D. R., and Varshney, R. K. 2011. Novel SSR markers from BAC-end sequences, DArT arrays and a comprehensive genetic map with 1,291 marker loci for chickpea (Cicer arietinum L.). PLoS One 6:e27275.

Trabanco, N., Pérez-Vega, E., Campa, A., Rubiales, D., and Ferreira, J. J. 2012 Genetic resistance to powdery mildew in common bean. Euphytica 186: 875-882.

Urano, D., Chen, J.-G., Botella, J. R., and Jones, A. M. 2013. Heterotrimeric G protein signalling in the plant kingdom. Open Biol. 3:120186.

Valdisser, P. A. M. R., Pereira, W. J., Almeida Filho, J. E., Müller, B. S. F., Coelho, G. R. C., de Menezes, I. P. P., Vianna, J. P. G., Zucchi, M. I., Lanna, A. C., Coelho, A. S. G., de Oliveira, J. P., Moraes, A. D. C., Brondani, C., and Vianello, R. P. 2017. In-depth genome characterization of a Brazilian common bean core collection using DArTseq high-density SNP genotyping. BMC Genomics 18:423.

van Ooijen, J. W. 2006. JoinMap 4, Software for the Calculation of Genetic Linkage Maps in Experimental Populations. Kyazma B. V., Wageningen, Netherlands. 
van Ooijen, J. W. 2009. MapQTL 6, Software for the Mapping of Quantitative Trait Loci in Experimental Populations of Diploid Species. Kyazma B. V., Wageningen, Netherlands.

Vaz Patto, M. C., Fernández-Aparicio, M., Moral, A., and Rubiales, D. 2006a. Characterization of resistance to powdery mildew (Erysiphe pisi) in a germplasm collection of Lathyrus sativus. Plant Breed. 125:308-310.

Vaz Patto, M. C., Fernández-Aparicio, M., Moral, A., and Rubiales, D. 2007. Resistance reaction to powdery mildew (Erysiphe pisi) in a germplasm collection of Lathyrus cicera from Iberian origin. Genet. Resour. Crop Evol. 54:1517-1521.

Vaz Patto, M. C., and Rubiales, D. 2014. Lathyrus diversity: Available resources with relevance to crop improvement $-L$. sativus and $L$. cicera as case studies. Ann. Bot. 113:895-908.

Vaz Patto, M. C., Skiba, B., Pang, E. C. K., Ochatt, S. J., Lambein, F., and Rubiales, D. 2006b. Lathyrus improvement for resistance against biotic and abiotic stresses: From classical breeding to marker assisted selection. Euphytica 147:133-147.

Vipin, C. A., Luckett, D. J., Harper, J. D. I., Ash, G. J., Kilian, A., Ellwood, S. R., Phan, H. T., and Raman, H. 2013. Construction of integrated linkage map of a recombinant inbred line population of white lupin (Lupinus albus L.). Breed. Sci. 63:292-300

Vishwakarma, M. K., Pandey, M. K., Shasidhar, Y., Manohar, S. S., Nagesh, P., Janila, P., and Varshney, R. K. 2016. Identification of two major quantitative trait locus for fresh seed dormancy using the diversity arrays technology and diversity arrays technology-seq based genetic map in Spanish-type peanuts. Plant Breed. 135:367-375.
Voigt, C. A. 2016. Cellulose/callose glucan networks: The key to powdery mildew resistance in plants? New Phytol. 212:303-305.

Voorrips, R. E. 2002. MapChart: Software for the graphical presentation of linkage maps and QTLs. J. Hered. 93:77-78.

Vu, H. T. T., James, A. T., Lawn, R. J., Bielig, L. M., and Kilian, A. 2015. Use of DArT molecular markers for QTL analysis of drought-stress responses in soybean. I. Phenotypic evaluation of traits. Crop Pasture Sci. 66:802.

Wang, L., Pei, Z., Tian, Y., and He, C. 2005. OsLSD1, a rice zinc finger protein, regulates programmed cell death and callus differentiation. Mol. Plant-Microbe Interact. 18:375-384

Xing, H., Fu, X., Yang, C., Tang, X., Guo, L., Li, C., Xu, C., and Luo, K. 2018 Genome-wide investigation of pentatricopeptide repeat gene family in poplar and their expression analysis in response to biotic and abiotic stresses. Sci. Rep. 8:2817.

Yan, J., Yuan, S. S., Jiang, L. L., Ye, X. J., Ng, T. B., and Wu, Z. J. 2015. Plant antifungal proteins and their applications in agriculture. Appl. Microbiol. Biotechnol. 99:4961-4981.

Yang, S. Y., Saxena, R. K., Kulwal, P. L., Ash, G. J., Dubey, A., Harper, J. D. I., Upadhyaya, H. D., Gothalwal, R., Kilian, A., and Varshney, R. K. 2011. The first genetic map of pigeon pea based on diversity arrays technology (DArT) markers. J. Genet. 90:103-109.

Zhang, H., Gao, Z., Zheng, X., and Zhang, Z. 2012. The role of G-proteins in plant immunity. Plant Signal. Behav. 7:1284-1288.

Zhang, Y., Lubberstedt, T., and Xu, M. 2013. The genetic and molecular basis of plant resistance to pathogens. J. Genet. Genomics 40:23-35. 